Skinner, C. E. (1947). Staff Meetings Bull., Univ. Minnesota, 18, 267.

Stoddard, J. L. (1917). Brit. med. J., 2, 416.

Stuhler, L. G. (1933). Proc. Mayo Clin., 8, 221.

Stunkard, H. W. (1946). J. Parasit., 32, 539.

Symonds, C. P. (1917). Lancet, 2, 769.

Syverton, J. T., and Berry, G. P. (1947). J. exp. Med. 86, 145.

Thygeson, P., and Stone, W. (1942). Arch. Ophthal., Chicago, 27, 91.

Touraine, A., and Vialatte (1936). Bull. Soc. franc. Derm. Syph., 43, 284.

Vargas-Zalazar, R. (1937). Rev. Soc. chil. Urol., 1, 96. (1944). Arch. Soc. Circuj. Hosp., 14, 346.

Vassallo, S. M. (1946). Brit. J. Urol., 18, 189.

Visher, J. W. (1929). J. Amer. med. Ass., 92, 2098.

Wagner, O., and Hees, E. (1935). Z Zbl. Bakt., 135, 310.
Wagner, O., and Hees, E. (1937). Zbl. Bakt., 138, 273. Wallman, D. R. (1946). Med. J. Aust., $2,93$.

Watson, J. M. (1947). Trop. Dis. Bull., 18, 337.

Weissenbach, R. J., Martineau, J., and Fourestier, M. (1934). Bull. Soc. franc. Derm. Syph., 41, 765.

Weyrauch, H. M. (1947). Calif. Med., 65, 104.

- and Gass, H. (1946). J. Urol., 55, 90.

Wheatley, D. P. (1946). Brit. med. J., 2, 837.

Wildbolz, H. (1933). XXXIII Congr. franc. Urol., p. 719. (1937). J. Urol., 37, 605.

Williams, B. (1946). Brit. J. Urol., 18, 63.

Williams, S. (1946). Med. J. Aust., 1, 693.

Wilson, G. H. (1930). J. Path. Bact., 33, 957.

Winsbury-White, H. P. (1933). 'Brit. J. Urol., 5, 249.

Wollstein, M. (1918). J. exp. Med., 28, 377.

Wright, L. T., Spencer, G. A., and Oppenheim, A. (1947). Amer. J. Syph., 31, 282.

\title{
DISCUSSION ON NON-BACTERIAL INFECTION OF THE URINARY TRACT
}

Mr. A. J. KING said that the Society was indebted to Dr. Coutts for his interesting address and also for drawing attention to this greatly neglected subject, not only at this meeting but in many medical journals for years past. He was glad that Dr. Coutts insisted so strongly upon the importance of the clinician instituting the preliminary laboratory investigations kimself, and examining fresh specimens of the secretions.

At the Whitechapel Clinic he and his colleagues were particularly interested in the problem of chronic prostatitis, which was such a difficult problem in their work-a condition resistant to treatment of all kinds. During the last few weeks Dr. Atlas had examined under the dark field of the microscope specimens from the prostatic fluid of a number of these cases, and had found spirilla in the prostatic secretion in a number of them. It still remained to be established whether these spirilla were the cause of the condition, and in fact, whether they were pathogenic at all. The findings confirmed Dr. Coutts's observation and opened a field for further investigation. Some of these patients had been treated with neoarsphenamine, but up to the present the results had been disappointing. Perhaps the drug was not being used as it should be, and if so he hoped that Dr. Coutts would put them right on points of technique. He felt that, in using a drug such as neoarsphenamine, or similar arsenicals, it was important to be very sure of the indications because it was a toxic drug, and already, in these cases, there had been some toxic manifestations.

Dr. Atlas said that he started to investigate a group of cases of chronic and residual prostatitis, all of which showed an abnormal number of polymorphonuclear leucocytes on microscopic test of a number of specimens of the prostatic fluid. Forty cases had been investigated so far, and fresh specimens of the prostatic fluid had been examined under dark-field illumination. Spirilla such as Dr. Coutts had described were found in sixteen cases out of forty ( 40 per cent.), and had been found again on repetition of the tests. In two cases there were very thin hair-like spirilla. In the other fourteen cases there were spirilla of the coarser type similar to those described by Dr. Coutts. The organisms were inclined to sink into the fluid, and a good deal of patience was required in order to find them and examine them properly.

Those cases with positive findings were treated withneoarsphenamine or arsenoxide ; $0.3 \mathrm{~g}$. neoarsphenamine or $0.04 \mathrm{~g}$. mapharside was given twice in the first week followed by $0.45 \mathrm{~g}$. neoarsphenamine or $0.06 \mathrm{~g}$. mapharside at weekly intervals, to a total of six injections. So far treatment had been completed in six cases, but the results were disappointing. Spirilla were still present and the number of polymorphonuclear leucocytes had not decreased.

DR. ROBERT LeEs said that he also had found nonspecific urethral infections extremely difficult and puzzling. There were vast numbers of such cases, and they appeared to have no relation to gonococcal or other pyogenic infections of the urethral tract, but he thought the majority were certainly infectious. The usual investigations carried out by bacteriologists were quite useless in such cases, and it was common experience to find that the bacteriologist was reluctant to pursue any other investigation than a search for gonococci.

During the last year he had made some investigations, but they had proved unsatisfactory. Firstly he had tested a considerable number of cases of non-gonococcal urethritis with Frei antigen, and practically no positive results were obtained. Also over a hundred cases . of urethritis, in whom gonococcal infection had been excluded, were treated with small doses of neoarsphenamine. Three doses of $0.3 \mathrm{~g}$. were given at intervals of three or four days. If a distinct response had not been obtained after three injections, the treatment was abandoned. The number of cases which responded in this way was extremely small, and he was convinced that this was not a promising line of non-specific treatment. In addition there was the fear of concealing incubating syphilis. The conclusion from this clinical investigation was that the type of urethritis with which we were dealing in this country was probably not due to the virus of 
lymphogranuloma inguinalæ, and did not respond to neoarsphenamine.

Severe metastatic lesions associated with a previous history of urethritis were extremely puzzling, and he would be grateful if Dr. Coutts would indicate whether such a condition as aortitis was likely to be related to previous urethritis or non-specific genito-urinary infections. During the last two years he had observed two severe progressive and fatal cases of aortitis, which were not syphilitic but which had been preceded some years previously by non-gonococcal urethritis.

He asked Dr. Coutts for guidance on the best technique for the detection of spiral organisms in urine, as he found it very difficult by simple examination of the centrifuged deposit of urine to obtain the high percentage of positive results described by others.

He had a strong impression that cases of abacterial pyuria which were likely to respond to treatment with neoarsphenamine always had an extremely acid urine, which it was difficult to render alkaline even by very high doses of citrates or similar drugs.

DR. MASCALl asked if there was any particular method of obtaining prostatic fluid for examination for spirochætes and trichomonads. He had done three series each of a hundred cases using the ordinary bead massage technique and had found only a small percentage of positive specimens for trichomonads. In one series he found 2 per cent. and in the other two 1 per cent. He wondered whether just carrying out an ordinary prostatic massage was sufficient or whether one should employ some previous preparation, such as washing out the urethra and bladder with sterile saline before collecting the specimen.

Like Dr. Lees he would like to know whether there was any particular method of treating specimens of urine, before looking for spirochætes. He was a little puzzled about the use of arsenicals, and whether the results justified the risk of producing dermatitis in the treatment of these cases. As far as trichomonads were concerned, when he was at the Whitechapel Clinic with Colonel Burke, they were giving a course of arsenical injections totalling $1 \mathrm{~g}$. per week for syphilis and the trichomonas vaginalis lived very happily, quite unaffected by this dose. Why a pentavalent preparation should be more efficacious he did not quite understand. Also he would like to ask Dr. Coutts whether he had any evidence of spore formation in trichomonas infections.

He had been observing these organisms for many years, and in the same case they were present on some days and on others could not be found. Relapses occurred with great frequency; or perhaps it was more correct to assume that these were re-infections.

He was of the confirmed opinion that re-infection occurred from the anus, although he was aware that this view was not universally supported. If he was wrong, surely there must be some resting or spore stage in the life cycle of $T$. vaginalis; otherwise how could these frequent relapses which occurred even during treatment be explained?

Surg.-Lieut. Cozens-Hardy said that there was a patient at the present time in the naval wing at Cosham with non-specific urethritis in whose urine and urethral discharge two varieties of spirochætes had been found on several days in succession. So far the patient had only been given two injections of neoarsphenamine. In another case of non-specific urethritis the scrotum became swollen after two weeks and later spontaneously subsided, leaving a very hard nodule in the lower pole of the right epididymis. Gonococci were not found, and he wondered w!ıther the condition could have been caused by a virus.

Dr. A. H. Harkness (President) said he had observed only a few cases of urethritis in the male due to fungi but a fair number due to the protozoan $T$. vaginalis, and he had recently examined a case of amœbic urethritis under the care of Dr. Murgatroyd. He wondered whether spirochætes found in the urethral discharge and urine were responsible for the urethritis, as in his experience the administration of neoarsphenamine was rarely successful. A few days ago Surg.-Comdr. Maguire demonstrated to Dr. Coutts and himself a case of primary abacterial urethritis in which two varieties of spirochætes were present in the urethral discharge and urine.

A doctor's son was recently sent to him with a diagnosis of Reiter's disease. The previous history showed that two injections of neoarsphenamine had been given for primary abacterial urethritis and on the day following the second injection the patient developed an itchy erythematous eruption, suffused conjunctivæ, high temperature, and pains in the joints. The case was considered to be one of Milian's ninth-day erythema.

Dr. Coutts had not mentioned pleuropneumonia-like or " $L$ " organisms and it was possible that he regarded them as saprophytes.

In a recent series of cases on non-gonococcal urethritis Henderson-Begg and he had attempted to correlate the finding of " $L$ " organisms in culture with the different types of this disease. The organisms were cultured from twenty-one of fifty-seven cases of subacute abacterial or Waelsch urethritis and from five of ten cases of acute abacterial urethritis but from only two of seventy-four cases of bacterial urethritis. These organisms were also cultured from twelve of forty-six cases of non-gonococcal cervicitis. Fifty normal males were also examined, and in no cases were " $\mathrm{L}$ " organisms recovered, which was in agreement with the work carried out by Beveridge and his collaborators in Australia. (See article by Harkness and Henderson-Begg in the British Journal of Venereal Diseases for June, 1948, p. 50.)

" L" organisms were also cultured in seven of forty-one cases of Reiter's disease, but cultures of synovial fluid, conjunctival secretion, and skin lesions were invariably negative. However, Dienes and Smith had recently isolated " $\mathrm{L}$ " organisms in the synovial fluid from two cases of Reiter's disease. These organisms were also isolated in two of sixteen cases of abacterial pyuria with no clinical evidence or history of urethritis, and the lower percentage might be due to the difficulties of isolation in urine.

The high percentage of positive cultures in certain types of abacterial urethritis of venereal origin, their absence from normal cases, their disappearance after successful treatment, the recurrence of positive cultures with the recurrence of lesions, and the effects of treatment on this condition, all supported the conclusion that "L" organisms might be responsible for certain types of urethritis.

Even in England, where lymphogranuloma inguinale was comparatively rare, there were cases of urethritis and cervicitis in adults and of virus conjunctivitis in babies, but so far no one has succeeded in culturing the virus. Dr. Harkness said that Dr. Hamilton Paterson who was collaborating with Dr. Henderson-Begg and himself had done some excellent work on inclusion cervicitis. He was unable to be present that afternoon 
but Dr. Dossett would read a short statement from him and show a few slides.

Dr. Dossetr (for Dr. Hamilton Paterson) showed some slides made from scrapings taken at the portio of the female cervix, and stated that the rounded transitional cells had been found in some cases to contain cytoplasmic inclusions which had been assumed to be due to a virus infection. From a variety of the inclusions it had been possible to demonstrate a line of development of the intra-cellular inclusions in trachoma and inclusion blenorrhœa.

Sorsby and Thygeson had claimed that inclusion blenorrhœa in the new-born was due to the eye becoming infected from the mother's cervix during passage through the birth canal, and the life cycle of the inclusions described was the same as that in the slides now shown. Thygeson also claimed to have isolated similar inclusions from the urethra of the father in a family where the mother and baby respectively had inclusion cervicitis and inclusion blenorrhœa.

Dr. Suchetr-Kaye said that he had been interested in the arthritic manifestations of these cases of nonspecific urethritis. He had not come to any conclusion about them nor found any references as to whether they were acute inflammatory conditions, or whether the arthritic manifestations were allergic and due to the presence of the organisms in the genito-urinary tract or the urethra. Had Dr. Coutts tried to culture organisms from the fluid in cases of arthritis, and were the results of treatment as successful for the arthritis as for the urethritic condition?

DR. Thomson said that for the recognition of $T$. vaginalis dark-ground microscopy was essential. When this method was not available an attempt was made to demonstrate their presence in stained specimens. He would be glad to know Dr. Coutts's method of staining the trichomonads. With regard to monilia infections, he found they were frequent in the female, especially in pregnant women, but in the male they were rare.

DR. CouTts, in reply, said : " Because of the necessity of keeping the paper within a reasonable limit of time I did not refer extensively to a very important aspect of the problem, probably one that can explain the origin and nature of many of these cases of non-bacterial infections of the genito-urinary tract. Sexual intercourse is practised in many different ways, some normal, some close to normal, and others abnormal. When masses of men are transported from one part of the world to another they come into contact and copulate, either normally or abnormally, with women of all conditions and nationalities. Many of these women have been infected, either through normal or abnormal sexual practices, and harbour in their genitalia such non-bacterial agents as were mentioned in our paper. Owing to the fact that most of these non-bacterial infections follow a subclinical course men who visit new territories and return home infect other women or their own wives, thus setting up a new. cycle of infection. This would explain the greater number of cases registered during and after the war years in countries where such infections were practically unknown.

Another point of interest in the spread of this type of infections is the physician's neglect to give importance to subclinical manifestations. Many specialists look at a cervix or a urethra carelessly. If there is no ulcer on the cervix which calls for attention, he does not bother to investigate whether the mucoid discharge contains more leucocytes than would normally be expected. If ten to fifteen polymorphonuclear leucocytes are found per microscope field, a subclinical infection must be suspected and the presence of micro-organisms investigated, especially under dark-field illumination. If they are not found slides must be stained and viruses (inclusion bodies in epithelial cells) searched for. The "morning drop " is another puzzle. If it is of the residual postgonococcal type it is well understood that every effort should be made to clear up the existence of a latent gonococcal infection. If all bacteriological evidence is negative we must at once consider the possibility that a non-bacterial agent may be maintaining the inflammatory process.

Several people have asked about the treatment of these non-bacterial infections and especially of those produced by spirochætes. Mixed infections-by trichomonas, spirochætes, viruses, etc.-are frequently observed in males ; this is not surprising, as we commonly find mixed infections in women. When the infection is produced by a single one of these agents the use of adequate drugs is followed by a rapid cure; but when it is of the mixed type treatment installed in relation to dark-field findings will undoubtedly improve conditions but not cure the patient. This observation must induce us to search for some of the other agents not visible under dark-field illumination-viruses, fungi, etc.

As regards the treatment of pure spirochætal infections and the poor results registered by some of the members of the Society after treating cases according to our recommendations as appeared in the British Medical Journal, of Dec. 28, 1946, p. 982, I will recall that all of us have undoubtedly observed early syphilis cases that have been cured clinically and serologically after one, two, or three injections of some arsenic compound, as revealed by follow-up for years afterwards. We have also seen cases cured with surprisingly small doses of penicillin. The contrary has assuredly also been observed by all of us (arseno-, bismuth-, etc. resistant syphilis). In some cases we obtain excellent and rapid results with neoarsphenamine, in others with arsenoxide. In other cases treatment with these drugs has to be prolonged. We advocated the use of pentavalent arsenicals because spirochætoidea have been found in the cervix of prostitutes who had shortly before been under syphilitic cures with trivalent arsenicals, arsenoxide, bismuth, or penicillin. When treatment has seemed unsuccessful we have associated local therapy with arsenic-glycerin in cervix ulcers, and in men, have given instillations of 'pergonon' or a 1 in 4,000 acriflavine solution in the urethra.

I was asked about the staining of these spirochætes. As published by us in 1935 (Derm. Wschr., 99, 1242) these spirochætes stain rapidly with a dilute solution of carbol-fuchsin.

Dr. Lees asked some important questions. The one referring to aortitis is of enormous interest, especially in relation to lymphogranuloma venereum. Technique for dark-field observation of proto- or metazoa does not vary from the usual. Material must be fresh and should be diluted with normosalt when pus is very abundant. This will allow micro-organismis a larger space for circulating or moving their cilia, thus rendering their detection easier. If slides cannot be observed under a thermo-regulated microscope, normosalt at $37^{\circ} \mathrm{C}$. should be dropped regularly on the borders of the cover glass. Movements may also be increased by adding isotonic glucose solution in the same way. 
The question regarding aortitis I will answer referring to investigations made in cases of lymphogranuloma venereum. In 1932, Caffa and Fulga (Bull. Soc. Méd. Hop. Bucarest, 14, 501) described a case of phlebitis of the femoral vein in a patient with homolateral lymphogranuloma venereum; in 1943 May, from Uruguay, described a case of thrombo-angiitis of the Leo-Buerger type and proved its lymphogranulomatous nature. In 1945 (J. trop. Med. Hyg., 48, 46) we studied in a number of young adults the possibility that certain vascular conditions-arteriosclerosis, periarteritis nodosa, etc.might be of lymphogranulomatous nature, and in the vascular wall of some cases found the presence of granulo-corpuscles and inclusion bodies as found in other lymphogranuloma venereum lesions. Most of these patients had a positive Frei test. We also found viral forms in two fragments of valvular vegetation (J. trop. Med. Hyg., 1942, 45, 137).

Dr. Dossett presented five excellent slides showing developmental phases of a virus found in the vagina. During my address I referred to Natalia Saez's investigations on inclusion bodies found in epithelial cells, and to her conclusion that only in 25 per cent. of positive cases could such inclusions be considered as of the nature of lymphogranuloma venereum. The slides shown by Dr. Dossett renind us of the viral forms described by
Thygeson and Stone in the cervix uteri of new-born infants with inclusion conjunctivitis.

I do not know what I should say about pleuropneumonia-like organisms; I believe it is better to leave the question open. They might well represent a developmental phase of some of these viruses, although it is strange that these organisms have so far not been cultured on living tissues and have been cultured in artificial media. The only way I would really be convinced that pleuropneumonia-like organisms can produce Reiter's disease would be on voluntary inoculation of this material and the appearance of the syndrome complex following experimental infection.

As regards viral infection, we must also remember Behcet's syndrome-aphthous lesions of mouth and genitalia, and ocular manifestations. Espildora has found in the papilla and ocular fundus of cases studied by us lesions as observed in cases of lymphogranuloma venereum.

We have seen several cases of arthritis but have not made cultures of synovial fluid. We will in the future inoculate chick embryos with this material in order to try and clear up the problem.

Up to the present not many specialists have been interested in the study of abacterial infections of the genitalia, but this afternoon I have found quite a number who are." 